\title{
PENGARUH METODE PEMBELAJARAN DAN MOTIVASI BELAJAR SISWA TERHADAP HASIL BELAJAR IPA KELAS V SDN CILAMAYA WETAN - KARAWANG
}

\author{
Yulistina Nur DS \\ PGSD FKIP UBP Karawang \\ yulistinanurds@yahoo.com
}

\begin{abstract}
The purpose of this study was to determine the extent of the influence of the use teaching methods and motivation on student science learning achievement, especially on teaching science to elementary students. The method used analysis model treatment by level (two-way) ANOVA. Experiments carried out on two groups or samples where each group was given treatment is different. The result of the analysis prove that: (1) there is the influence of learning methods on science learning achievement, (2) there is in effect on the motivation to science learning achievement, (3) there is no interaction effect between learning methods and motivation on science learning achievement.
\end{abstract}

Key words: Method of learning, Inquiry, Science Learning Achievement.

\begin{abstract}
Abstrak: Tujuan dari penelitian ini adalah untuk mengetahui sejauh mana pengaruh penggunaan metode pembelajaran dan motivasi belajar terhadap hasil belajar IPA siswa, terutama pada mata pelajaran IPA untuk siswa SD. Metode yang digunakan yaitu model analisis pengolahan dengan tingkat (dua arah) ANOVA. Percobaan dilakukan pada dua kelompok atau sampel dimana setiap kelompok diberi perlakuan berbeda . Hasil analisis membuktikan bahwa :(1) ada pengaruh metode pembelajaran terhadap hasil belajar ilmu pengetahuan, (2) ada pengaruh antara motivasi terhadap hasil belajar ilmu pengetahuan , (3) tidak ada pengaruh interaksi antara metode pembelajaran dan motivasi terhadap hasil belajar ilmu pengetahuan.
\end{abstract}

Kata Kunci: Metode Pembelajaran, inkuiri, Hasil Belajar IPA 


\section{PENDAHULUAN}

Pendidikan dalam arti yang luas merupakan bagian yang hakiki dari kehidupan manusia. Oleh karena itu pendidikan menjadi masalah penting bagi suatu bangsa, lebih lagi bagi bangsa yang sedang membangun, seperti bangsa Indonesia pada saat ini.

Oleh karena itu, maka Sekolah Dasar merupakan sebuah lembaga pendidikan dasar yang diberikan tugas sangat penting sebagai upaya untuk meningkatkan pengetahuan siswa dalam proses pembelajaran di dalam kelas, sehingga pelaksanaan pendidikan di Sekolah Dasar memperoleh perhatian penuh oleh guru untuk menerapkan metode pembelajaran yang tepat sebagai dasar peningkatan kualitas guru dalam proses pembelajaran yang lebih efektif.

Belajar IPA bukan hanya untuk memahami konsep-konsep ilmiah dan aplikasinya dalam masyarakat, melainkan juga untuk mengembangkan berbagai nilai (Cross dalam Samatowa, 2010:8). Mata pelajaran IPA menyediakan berbagai pengalaman belajar untuk memahami konsep dan proses. Pengalaman belajar didapat oleh peserta didik ketika melakukan kegiatan pembelajaran. Pada saat itulah peserta didik diajak untuk ikut aktif dalam kegiatan pembelajaran sehingga peserta didik dapat memperoleh pengalaman secara langsung dan lebih mudah memahami materi pelajaran yang diberikan. Peran aktif siswa dalam kegiatan pembelajaran diharapkan dapat membuat siswa membangun pemahaman terhadap konsep materi pelajaran dari pengalaman sehingga siswa lebih memahami dan menguasai materi yang dipelajari.

Dalam pembelajaran IPA terkadang ada fenomena yang sulit diamati, didengar, diraba dan dirasakan secara langsung. Dalam mempelajari IPA, peserta didik terkadang mengalami kesulitan karena IPA merupakan ilmu yang membutuhkan pemahaman terhadap materi yang akan diberikan. Kurangnya pemahaman siswa terhadap ilmu IPA dan rendahnya aktivitas siswa dalam pembelajaran 
IPA dapat disebabkan karena siswa belum memahami konsep yang dijelaskan oleh guru dan juga pembelajaran yang bersifat verbalistis yang menyebabkan siswa jarang ikut aktif dalam kegiatan pembelajaran (Desviranty, 2011:5). Terlebih lagi jika guru tersebut hanya menggunakan metode ceramah saat memberikan materi pelajaran, sehingga peserta didik merasa bosan karena ia hanya duduk, diam, mencatat, dan mendengarkan guru menjelaskan materi pelajaran. Selain itu hal tersebut akan membuat siswa semakin tidak termotivasi untuk memahami IPA karena pembelajaran hanya bersifat satu arah saja, akibatnya kreativitas dan keterampilan siswa akan terhambat.

Hasil belajar dipengaruhi oleh berbagai faktor, yang meliputi faktor internal dan eksternal. Faktor internal merupakan faktor yang mempengaruhi yang berasal dari dalam diri siswa yang meliputi, bakat, minat, sikap, motivasi, dan keterampilan yang ada pada dirinya. Motivasi yang tinggi terhadap suatu mata pelajaran, memungkinkan siswa memberikan perhatian yang tinggi terhadap mata pelajaran itu sehingga memungkinkan pula memperoleh hasil belajar yang tinggi, sebagai akibat dari ketertarikan siswa terhadap suatu mata pelajaran.

Guru adalah seorang pendidik, pembimbing, pelatih dan pemimpin yang dapat menciptakan iklim belajar menarik, aman, nyaman dan kondusif di kelas, keberadaannya di tengah siswa dapat mencairkan suasana kebekuan, kekakuan dan kejenuhan belajar yang terasa berat diterima siswa. Iklim yang tidak kondusif akan berdampak negatif terhadap proses pembelajaran, siswa akan merasa gelisah, resah, bosan dan jenuh. Sebaliknya iklim belajar yang kondusif dan menarik dapat dengan mudah tercapainya tujuan pembelajaran, dan proses pembelajaran yang dilakukan menyenangkan bagi peserta didik. Sehingga akan tumbuh motivasi siswa pada pelajaran IPA yang pada gilirannya akan tercapai hasil belajar yang optimal.

Proses belajar mengajar akan lebih menarik apabila guru dapat memilih dan menggunakan metode pembelajaran yang relevan dengan 
konsep yang sedang dipelajari sehingga tujuan pembelajaran dapat tercapai. Salah satu metode pembelajaran yang memberikan porsi ruang dan waktu terbesar kepada siswa adalah metode pembelajaran inkuiri. Melalui metode pembelajaran inkuiri siswa diajak untuk terlibat langsung kedalam proses ilmiah melalui latihan-latihan.

Bertitik tolak dari beberapa pernyataan dan fakta yang dihasilkan dari beberapa penelitian di atas, maka melalui penelitian ini akan dikaji "Pengaruh Metode Pembelajaran (Inkuiri dan Konvensional) dan Motivasi Belajar Siswa Terhadap Hasil Belajar IPA Kelas V Sekolah Dasar".

Menurut Slameto (2010:2) belajar dapat didefinisikan sebagai suatu proses usaha yang dilakukan seseorang untuk memperoleh suatu perubahan tingkah laku yang baru secara keseluruhan, sebagai hasil pengalamannnya sendiri dalam interaksi dengan lingkungannya. Selanjutnya menurut Hamalik (2009:27) belajar adalah modifikasi atau memperteguh kelakuan melalui pengalaman (Learning is defined as the modification or strengthening of behavior through experiencing). Menurut pengertian ini, belajar merupakan suatu proses, suatu kegiatan dan bukan suatu hasil atau tujuan. Belajar bukan hanya mengingat, akan tetapi lebih luas dari itu, yakni mengalami. Hasil belajar bukan suatu penguasaan hasil latihan melainkan pengubahan kelakuan. Robert M. Gagne (dalam Sagala, 2010:17) menyatakan bahwa belajar merupakan kegiatan yang kompleks, dan hasil belajar berupa kapabilitas, timbulnya kapabilitas disebabkan: (1) stimulasi yang berasal dari lingkungan; dan (2) proses kognitif yang dilakukan oleh pelajar. Setelah belajar orang memiliki keterampilan, pengetahuan, sikap, dan nilai. Dengan demikian dapat ditegaskan, belajar adalah seperangkat proses kognitif yang mengubah sifat stimulasi lingkungan, melewati pengolahan informasi, dan menjadi kapabilitas baru.

Ernes ER. Hilgard (dalam Riyanto, 2009:4) mendefinisikan belajar sebagai berikut: learning is the process by which an activity originates or is charged throught 
training procedures (whether in the laboratory or ib the natural environments) as disitinguished from changes by factor not attributable to training. Artinya seseorang dapat dikatakan belajar kalau dapat melakukan sesuatu dengan cara latihan-latihan sehingga yang bersangkutan menjadi berubah. Dari pendapat-pendapat ahli di atas dapat disimpulkan bahwa belajar adalah segenap rangkaian kegiatan atau aktivitas yang dilakukan secara sadar oleh seseorang dan mengakibatkan perubahan dalam dirinya berupa penambahan pengetahuan atau kemahiran berdasarkan alat indera dan pengalamannya. Oleh sebab itu apabila setelah belajar peserta didik tidak ada perubahan tingkah laku yang positif dalam arti tidak memiliki kecakapan baru serta wawasan pengetahuannya tidak bertambah maka dapat dikatakan bahwa belajarnya belum sempurna.

Menurut

Suryosubroto (1997:149) mengemukakan bahwa metode adalah cara yang dalam fungsinya merupakan alat untuk mencapai tujuan. Menurut Sapriati (31:2011) faktor-faktor yang perlu menjadi bahan pertimbangan dalam memilih metode pembelajaran yaitu:

1. Hendaknya sesuai dengan tujuan pembelajaran IPA

2. Hendaknya diadaptasikan dengan kemampuan siswa

3. Hendaknya sesuai dengan psikologi belajar

4. Hendaknya disesuaikan dengan bahan pengajaran

5. Hendaknya disesuaikan dengan alokasi waktu dan sarana prasarana yang tersedia

Dari beberapa pengertian di atas maka dapat diambil kesimpulan bahwa metode adalah suatu cara yang sistematis dalam menyampaikan pengetahuan dan fungsinya merupakan alat untuk mencapai tujuan.

Menurut Dimyati dan Mudjono (1999:297) pembelajaran adalah kegiatan guru secara terprogram dalam desain instruksional untuk membuat siswa belajar aktif yang menekankan pada penyediaan sumber belajar. Hamalik

(1995:57) mengemukakan bahwa pembelajaran adalah upaya mengorganisasi lingkungan untuk menciptakan kondisi belajar bagi peserta didik. Kegiatan ini meliputi unsur-unsur manusiawi, material fasilitas, perlengkapan dan prosedur yang 
saling mempengaruhi mencapai tujuan pembelajaran. Unsur manusiawi ini meliputi siswa, guru dan tenaga lainnya.

Dari pengertian di atas, maka yang dimaksud dengan pembelajaran adalah suatu kegiatan yang melibatkan guru, siswa dan komponen lainnya dalam rangka mencapai tujuan pembelajaran. Dengan kata lain, pembelajaran adalah suatu proses yang mengandung serangkaian perbuatan guru dan siswa atas dasar hubungan timbal balik yang berlangsung dalam situasi edukatif dan ditunjang oleh berbagai unsur lainnya untuk mencapai tujuan yang telah dirumuskan.

Dengan demikian, metode pembelajaran adalah cara yang digunakan dalam proses belajar mengajar untuk menyampaikan materi pembelajaran dari seorang guru kepada siswa dalam rangka pencapaian tujuan yang diharapkan. Dalam definisi tersebut terkandung makna bahwa dalam penerapannya ada kegiatan memilih, menetapkan, menggunakan dan mengembangkan metode yang optimal untuk mencapai hasil yang diinginkan.

Menurut Amri (2010:85) inkuiri berasal dari bahasa Inggris inquiry yang dapat diartikan sebagai proses bertanya dan mencari tahu jawaban terhadap pertanyaan ilmiah yang diajukan. Pertanyaan ilmiah adalah pertanyaan yang dapat mengarahkan pada kegiatan penyelidikan terhadap obyek pertanyaan. Menurut Encylopedia of Educational Research (dalam Suryosubroto, 2009:178) inkuiri merupakan suatu strategi yang unik dapat diberi bentuk oleh guru dalam berbagai cara, termasuk mengajarkan keterampilan menyelidiki dan memecahkan masalah sebagai alat bantu bagi siswa untuk mencapai tujuan pendidikannya. Sanjaya (2009:196) menyatakan bahwa inkuiri adalah rangkaian kegiatan pembelajaran yang menekankan pada proses berpikir secara kritis dan analitis untuk mencari dan menemukan sendiri jawaban dari suatu masalah yang dipertanyakan. Proses berpikir itu sendiri biasanya dilakukan melalui tanya jawab antara guru dan siswa. 
Suryosubroto

$(2009: 178)$

berpendapat bahwa metode inkuiri adalah suatu metode di mana dalam proses belajar mengajar guru memperkenankan siswa-siswanya menemukan sendiri informasi yang secara tradisional biasa diberitahukan atau diceramahkan saja. Gulo (dalam Trianto, 2011:166) menyatakan bahwa inkuiri berarti suatu rangkaian kegiatan belajar yang melibatkan secara maksimal seluruh kemampuan siswa untuk mencari dan menyelidiki secara sistematis, kritis, logis, analitis, sehingga mereka dapat merumuskan sendiri penemuannya dengan penuh percaya diri.

Sabri (2010:11) berpendapat bahwa inkuiri adalah pendekatan mengajar yang berusaha meletakkan dasar dan mengembangkan cara berpikir ilmiah. Asumsi dasar yang menjadi keyakinan pokok metode inkuiri berakar pada pendirian bahwa setiap anak memiliki kebiasaan berkembang. Di samping itu, menurut Suchman (dalam Apriadiastuti, 2008:10), anak memiliki motivasi alamiah untuk meneliti atau berinkuiri. Oleh karena itu inkuiri membutuhkan partisipasi aktif dari anak didik untuk meneliti sendiri secara ilmiah masalah yang dihadapi. Tetapi tidaklah berarti dengan inkuiri kita akan mendidik siswa menjadi seorang ilmuan, tetapi membawa anak ke dalam situasi yang memberikan kesempatan pada dirinya untuk menggunakan apa yang telah diketahui dan menyadari apa yang mereka lakukan itu adalah hasil perolehan mereka sendiri dan bukan perolehan guru.

Dari beberapa pendapat di atas tentang definisi inkuiri dapat disimpulkan bahwa inkuiri merupakan proses yang bervariasi dan meliputi kegiatan-kegiatan megobservasi, merumuskan pertanyaan yang relevan, merencanakan penyelidikan atau investigasi, mereview apa yang telah diketahui, melaksanakan percobaan atau eksperimen dengan menggunakan alat untuk memperoleh data, menganalisis dan menginterpretasi data, serta membuat prediksi dan mengkomunikasikan hasilnya.

Menurut Trianto (2011:114) siklus inkuiri terdiri dari 5 yaitu:

1. Observasi (Observation); 
2. Bertanya (Questioning);

3. Mengajukan dugaan (Hyphotesis);

4. Pengumpulan data (Data Gathering);

5. Penyimpulan (Conclussion). Adapun langkah-langkah kegiatan inkuiri adalah sebagai berikut (Trianto, 2011:115): 1) merumuskan masalah yang akan dipecahkan siswa; 2) mengamati atau melakukan observasi/ eksperimen; 3) menganalisis dan menyajikan hasil dalam tulisan, gambar, laporan, bagan, tabel, dan karya lainnya; 4) mengkomunikasikan atau menyajikan hasil karya pada pembaca, teman sekelas, guru, atau audiensi yang lainnya.

Istilah motivasi berpangkal dari kata "motif" yang dapat diartikan sebagai kekuatan yang terdapat dalam diri individu, yang menyebabkan individu tersebut bertindak atau berbuat (Uno, 2008:3). Menurut W.S Winkel (dalam Uno, 2008:3) motif adalah daya penggerak dalam diri seseorang untuk melakukan aktivitas tertentu, demi mencapai tujuan tertentu.

Eysenck, dll (dalam Slameto, 2010:170) berpendapat bahwa motivasi dirumuskan sebagai suatu proses yang menentukan tingkatan kegiatan, intensitas, konsistensi, serta arah umum dari tingkah laku manusia, merupakan konsep rumit dan berkaitan dengan konsep-konsep lain seperti minat, konsep diri, sikap, dan sebagainya.

Menurut Mc. Donald (dalam Hamalik, 2009:158) : motivation is an energy change within the person characterized by affective arousal and anticipatory goal reaction (motivasi adalah perubahan energi dalam diri (pribadi) seseorang yang ditandai dengan timbulnya perasaan dan reaksi untuk mencapai tujuan).

Menurut Uno (2008:1) motivasi adalah dorongan dasar yang menggerakkan seseorang bertingkah laku. Dorongan ini berada pada diri seseorang yang menggerakkan untuk melakukan sesuatu yang sesuai dengan dorongan dalam dirinya. Menurut Reid (2009:19) idealnya motivasi haruslah instrinsik yakni pembelajar memiliki motivasi diri (self-motivating). Akan tetapi, untuk meraihnya pembelajar perlu memiliki sasaran dan keinginan kuat untuk sukses. 
Berdasarkan beberapa pendapat di atas dapat disimpulkan bahwa motivasi adalah keseluruhan daya penggerak di dalam diri siswa yang menimbulkan, menjamin kelangsungan dan memberikan arah kegiatan belajar, sehingga diharapkan tujuan dapat tercapai.

Menurut Usman Samatowa (2006:2) ilmu pengetahuan alama (IPA) merupakan suatu ilmu yang mempelajari peristiwa-peristiwa yang terjadi di alam ini. Hal ini sesuai dengan pendapat Miarso $\mathrm{Y}$ (2004:646) dimana pada hakekatnya ilmu pengetahuan alam merupakan pengetahuan yang berakumulasi dan tersusun mengenai alam dan gejalanya.

Ruang lingkup bahan kajian IPA untuk SD/MI meliputi aspek-aspek sebagai berikut: (1) makhluk hidup dan proses kehidupan, yaitu manusia, hewan, tumbuhan dan interaksinya dengan lingkungan, serta kesehatan;(2) Benda atau materi, sifat-sifat dan kegunaannya meliputi: zat cair, padat dan gas; (3) Energi dan perubahannya meliput: gaya, bunyi, panas, magnet, listrik, cahaya dan pesawat sederhana; (4) Bumi dan alam semesta meliputi: tanah, bumi, tata surya, dan benda-benda langit lainnya.

\section{METODE PENELITIAN}

Penelitian dilakukan dengan menggunakan teknik eksperimen dengan membandingkan dua teknik pembelajaran yang berbeda, yakni teknik pembelajaran inkuiri dan teknik pembelajaran konvensional atau tradisional. Adapun desai penelitian ini menggunakan bentuk faktorial $2 \times 2$ yang terdapat tiga variabel penelitian, yaitu satu variabel terikat dan dua variabel bebas. Sebagai variabel terikat dalam penelitian ini yaitu hasil belajar IPA, sedangkan variabel bebas pada perlakukan pembelajaran dibedakan menjadi dua yaitu, metode pembelajaran inkuiri $\left(\mathrm{A}_{1}\right)$ untuk kelompok eksperimen dan metode pembejaran konvensional atau tradisional $\left(\mathrm{A}_{2}\right)$ untuk kelompok kontrol. Desain eksperimen penelitian ini dapat digambarkan melalui desain treatment by level 2 × 2 pada tabel 1 . di bawah ini: 
Tabel 1

Desain Penelitian

\begin{tabular}{|c|c|c|c|}
\hline \multirow{2}{*}{$\begin{array}{c}\text { Level }: \text { Tingkat } \\
\text { Motivasi } \\
\text { Belajar }(\mathrm{B})\end{array}$} & \multicolumn{2}{|c|}{ Treatment : Penggunaan Metode Pembelajaran (A) } & \multirow{2}{*}{$\sum \mathrm{B}$} \\
\cline { 2 - 4 } & Inkuiri $\left(\mathrm{A}_{1}\right)$ & Konvensional $\left(\mathrm{A}_{2}\right)$ & \\
\hline Tinggi $\left(\mathrm{B}_{1}\right)$ & $\mathrm{A}_{1} \mathrm{~B}_{1}$ & & $\sum \mathrm{B}_{1}$ \\
\hline Rendah $\left(\mathrm{B}_{2}\right)$ & $\mathrm{A}_{1} \mathrm{~B}_{2}$ & $\mathrm{~A}_{2} \mathrm{~B}_{1}$ & $\sum \mathrm{B}_{2}$ \\
\hline$\sum \mathrm{A}$ & $\sum \mathrm{A}_{1}$ & $\sum \mathrm{A}_{2}$ & \\
\hline
\end{tabular}

Populasi dalam penelitian ini adalah jumlah objek dan mempunyai karakter yang sama. Populasi penelitin ini adalah seluruh siswa SD Negeri Cilamaya Wetan. Sampel dalam penelitian ini adalah siswa kelas V SDN 01 Cilamaya Wetan yaitu sebanyak 30 siswa dan siswa kelas V SDN 02 Cilamaya Wetan yaitu sebanyak 30 siswa.

\section{HASIL PENELITIAN DAN PEMBAHASAN}

Data penelitian yang diperoleh dalam penelitian ini adalah data skor motivasi belajar dan data skor hasil belajar IPA. Data skor motivasi belajar hanya digunakan untuk menentukan tingkat (level) analisis.

Deskripsi data motivasi belajar dan hasil belajar IPA yang diperoleh dari responden selengkapnya bisa dilihat pada tabel berikut:

\section{Tabel 2 Deskripsi Statistik menurut Rancangan Penelitian dalam Format Output SPSS}




\section{Descriptive Statistics}

Dependent Variable: Hasil Belajar IPA

\begin{tabular}{|ll|r|r|r|}
\hline Kelas & Motivasi Belajar & Mean & Std. Deviation & N \\
\hline Kelas eksperimen (A1) & Motivasi Tinggi (B1) & 72.67 & 8.633 & 15 \\
& Motivasi Rendah (B2) & 69.33 & 11.159 & 15 \\
& Total & 71.00 & 9.948 & 30 \\
\hline Kelas Kontrol (A2) & Motivasi Tinggi (B1) & 63.00 & 12.507 & 15 \\
& Motivasi Rendah (B2) & 61.00 & 11.212 & 15 \\
& Total & 62.00 & 11.715 & 30 \\
& Motivasi Tinggi (B1) & 67.83 & 11.647 & 30 \\
\hline Total & Motivasi Rendah (B2) & 65.17 & 11.780 & 30 \\
& Total & 66.50 & 11.692 & 60 \\
\hline
\end{tabular}

Berdasarkan data ini eksperimen dapat dinyatakan menunjukkan bahwa berdasarkan berhasil. Kemudian jika dilihat dari Tabel 3 untuk kelas eksperimen (A1) motivasi belajar menunjukkan bahwa mempunyai rata-rata nilai 71.00 jauh untuk siswa dengan motivasi belajar lebih besar dibandingkan dengan tinggi mempunyai nilai rata-rata kelas kontrol dengan nilai rata-rata 67.83 lebih tinggi dibandingkan hanya sebesar 62.00. Secara deskriptif menunjukkan bahwa kelas dengan siswa dengan motivasi belajar rendah yaitu 65.1 .

Tabel 3

Deskriptif Statistik menurut Rancangan Penelitian

\begin{tabular}{|c|c|c|c|c|}
\hline \multirow{2}{*}{$\mathrm{B}$} & \multirow{2}{*}{ Stat } & \multicolumn{2}{|c|}{$\mathrm{A}$} & \multirow{2}{*}{ Total } \\
\cline { 2 - 4 } & & $\mathrm{A}_{1}$ & $\mathrm{~A}_{2}$ & \\
\hline \multirow{3}{*}{$\mathrm{B}_{1}$} & $\mathrm{n}$ & 15 & 15 & 30 \\
\cline { 2 - 4 } & $\bar{x}$ & 72.67 & 63.00 & 67.83 \\
\cline { 2 - 4 } & $\mathrm{s}$ & 8.633 & 12.507 & 11.647 \\
\hline \multirow{3}{*}{$\mathrm{B}_{2}$} & $\mathrm{n}$ & 15 & 15 & 30 \\
\cline { 2 - 4 } & $\bar{x}$ & 69.33 & 61.00 & 65.17 \\
\cline { 2 - 4 } & $\mathrm{S}$ & 11.159 & 11.212 & 11.780 \\
\hline \multirow{3}{*}{ Total } & $\mathrm{n}$ & 30 & 30 & 60 \\
\cline { 2 - 4 } & $\bar{x}$ & 71.00 & 62.00 & 66.50 \\
\cline { 2 - 4 } & $\mathrm{S}$ & 9.948 & 11.715 & 11.692 \\
\hline
\end{tabular}

Ada temuan pada analisis ini adalah untuk kelompok motivasi belajar tinggi secara umum mempunyai nilai rata-rata IPA lebih 
tinggi dibandingkan dengan ini yang diuji adalah hipotesis Nol kelompok motivasi belajar rendah.

1. Pengujian Persyaratan Analisis

a. Pengujian Normalitas Data

Untuk menentukan apakah $\left(\mathrm{H}_{0}\right)$. Untuk menolak $\mathrm{H}_{0}$ dilakukan dengan taraf signifikansi 0,05 atau membandingkan nilai signifikansi dengan berdasarkan kriteria berikut: variabel normal atau tidak maka dilakukan uji normalitas dengan menggunakan uji KolmogorovSmirnov dengan SPSS 16. Dalam hal

Jika nilai sig. > 0.05; maka data berdistribusi normal

Jika nilai sig. < 0.05; maka data tidak berdistribusi normal.

Tabel 4

Uji Normalitas Data Penelitian

One-Sample Kolmogorov-Smirnov Test

\begin{tabular}{|ll|r|}
\hline & & $\begin{array}{c}\text { Hasil Belajar } \\
\text { IPA }\end{array}$ \\
\hline $\mathrm{N}$ & & 60 \\
Normal Parameters $^{\mathrm{a}}$ & Mean & 66.50 \\
& Std. Deviation & 11.692 \\
Most Extreme Differences & Absolute & .126 \\
& Positive & .091 \\
& Negative & -.126 \\
Kolmogorov-Smirnov Z & & .975 \\
Asymp. Sig. (2-tailed) & & .298 \\
\hline
\end{tabular}

Dari hasil perhitungan dengan SPSS 16 di atas, menunjukkan bahwa nilai uji statistik KS untuk hasil belajar IPA yaitu 0.975 dan Sig. 0.298 $>0.05$ yang berarti data hasil belajar berdistribusi normal.

Pengujian homogenitas data hasil belajar IPA siswa dilakukan dengan uji lavene pada taraf Jurnal Sekolah Dasar, ISSN 2528-2883 Vol. 1 No. 1 Sept 2016 110 
Jika nilai sig. (levene's test) >

0.05; maka $\mathrm{H}_{0}$ diterima dan $\mathrm{H}_{1}$ ditolak
Jika nilai sig. (levene's test) < 0.05; maka $\mathrm{H}_{1}$ diterima dan $\mathrm{H}_{0}$ ditolak

Tabel 5

Ringkasan Hasil Perhitungan Uji Homogenitas Hasil Belajar IPA

Levene's Test of Equality of Error Variances ${ }^{\mathrm{a}}$

Dependent Variable:Hasil Belajar IPA

\begin{tabular}{|r|r|r|r|}
\hline F & df1 & df2 & Sig. \\
\hline .332 & & 36 & .802 \\
\hline
\end{tabular}

Tests the null hypothesis that the error variance of the dependent variable is equal across groups.

a. Design: Intercept $+\mathrm{A}+\mathrm{B}+\mathrm{A} * \mathrm{~B}$

Dari perhitungan data di atas dengan SPSS 16 diperoleh nilai sig. $0.802>0.05$ dengan demikian $\mathrm{H}_{0}$

\section{Pengujian Hipotesis Penelitian}

Setelah dilakukan uji normalitas dan homogenitas dan hasilnya menunjukkan bahwa sampel penelitian berasal dari populasi berdistribusi normal dan varians sampel homogen, maka pengujian diterima dan $\mathrm{H}_{1}$ ditolak dan data berasal dari populasi yang homogen.

hipotesis dengan menggunakan ANOVA dapat dilakukan. Analisis terhadap data hasil belajar siswa dilakukan dengan menggunakan ANOVA dua arah yang proses perhitngannya dibantu dengan program SPSS 16.

Tabel 6

\section{Ringkasan Hasil ANOVA}

Tests of Between-Subjects Effects

Dependent Variable:Hasil Belajar IPA

\begin{tabular}{|l|r|r|r|r|r|}
\hline Source & $\begin{array}{r}\text { Type III Sum of } \\
\text { Squares }\end{array}$ & df & Mean Square & \multicolumn{1}{|c|}{ F } & \multicolumn{1}{c|}{ Sig. } \\
\hline Corrected Model & $1328.333^{\mathrm{a}}$ & 3 & 442.778 & 3.681 & .017 \\
Intercept & 265335.000 & 1 & 265335.000 & $2.206 \mathrm{E} 3$ & .000 \\
$\mathrm{~A}$ & 1215.000 & 1 & 1215.000 & 10.100 & .002 \\
$\mathrm{~B}$ & 106.667 & 1 & 106.667 & .887 & .350 \\
$\mathrm{~A} * \mathrm{~B}$ & 6.667 & 1 & 6.667 & .055 & .815 \\
Error & 6736.667 & 56 & 120.298 & & \\
Total & 273400.000 & 60 & & & \\
Corrected Total & 8065.000 & 59 & & & \\
\hline
\end{tabular}


Tests of Between-Subjects Effects

Dependent Variable:Hasil Belajar IPA

\begin{tabular}{|l|r|r|r|r|r|}
\hline Source & $\begin{array}{c}\text { Type III Sum of } \\
\text { Squares }\end{array}$ & df & Mean Square & \multicolumn{1}{|c|}{ F } & \multicolumn{1}{c|}{ Sig. } \\
\hline Corrected Model & $1328.333^{\mathrm{a}}$ & 3 & 442.778 & 3.681 & .017 \\
Intercept & 265335.000 & 1 & 265335.000 & $2.206 \mathrm{E} 3$ & .000 \\
$\mathrm{~A}$ & 1215.000 & 1 & 1215.000 & 10.100 & .002 \\
$\mathrm{~B}$ & 106.667 & 1 & 106.667 & .887 & .350 \\
$\mathrm{~A} * \mathrm{~B}$ & 6.667 & 1 & 6.667 & .055 & .815 \\
Error & 6736.667 & 56 & 120.298 & & \\
Total & 273400.000 & 60 & & &
\end{tabular}

a. R Squared $=.165$ (Adjusted R Squared $=.120)$

Berdasarkan data di atas dapat disimpulkan :

\section{a. Pengujian Hipotesis 1 :}

$\mathrm{H}_{0}$ : Tidak terdapat pengaruh metode pembelajaran terhadap hasil belajar IPA

$\mathrm{H}_{1}$ : Terdapat pengaruh metode pembelajaran terhadap hasil belajar IPA

Hipotesis diuji dengan melihat koefisien signifikan.

Jika nilai sig. > 0.05; maka $\mathrm{H}_{0}$ diterima dan $\mathrm{H}_{1}$ ditolak

Jika nilai sig. $<0.05$; maka $\mathrm{H}_{1}$ diterima dan $\mathrm{H}_{0}$ ditolak

Dari pengujian dengan SPSS 16 di atas didapat sig. untuk metode pembelajaran $0.002<0.05$ dan $\mathrm{F}_{0}=$ 10.100 dengan demikian dapat disimpulkan terdapat pengaruh metode pembelajaran yang signifikan terhadap hasil belajar IPA.

\section{b. Pengujian Hipotesis 2 :}

$\mathrm{H}_{0}$ : Tidak terdapat pengaruh motivasi belajar terhadap hasil belajar IPA $\mathrm{H}_{1}$ : Terdapat pengaruh motivasi belajar terhadap hasil belajar IPA Hipotesis diuji dengan melihat koefisien signifikan.

Jika nilai sig. > 0.05 ; maka $\mathrm{H}_{0}$ diterima dan $\mathrm{H}_{1}$ ditolak

Jika nilai sig. $<0.05$; maka $\mathrm{H}_{1}$ diterima dan $\mathrm{H}_{0}$ ditolak

Dari pengujian dengan SPSS 16 di atas didapat sig. untuk motivasi belajar $0.350>0.05$ dan $\mathrm{F}_{0}=0.887$ dengan demikian dapat disimpulkan tidak terdapat pengaruh motivasi belajar yang signifikan terhadap hasil belajar IPA.

\section{c. Pengujian Hipotesis 3 :}


$\mathrm{H}_{0}$ : Tidak terdapat pengaruh interaksi metode pembelajaran dan motivasi belajar terhadap hasil belajar IPA $\mathrm{H}_{1}$ : Terdapat pengaruh interaksi metode pembelajaran dan motivasi belajar terhadap hasil belajar IPA Hipotesis diuji dengan melihat koefisien signifikan.

Jika nilai sig. > 0.05 ; maka $\mathrm{H}_{0}$ diterima dan $\mathrm{H}_{1}$ ditolak

Jika nilai sig. $<0.05$; maka $\mathrm{H}_{1}$ diterima dan $\mathrm{H}_{0}$ ditolak

Dari pengujian dengan SPSS 16 di atas didapat sig. untuk metode pembelajaran dan motivasi belajar $0.815>0.05$ dan $\mathrm{F}_{0}=0.055$ dengan demikian dapat disimpulkan tidak terdapat pengaruh interaksi metode pembelajaran dan motivasi belajar yang signifikan terhadap hasil belajar IPA.

Dari hasil analisis data di atas dapat diintepretasikan sebagai berikut:

1. Terdapat pengaruh metode pembelajaran terhadap hasil belajar IPA yang sangat signifikan. Hal ini ditandai dengan nilai sig. untuk metode belajar $0.002<0.05$ dengan demikian dapat disimpulkan terdapat pengaruh metode belajar terhadap hasil belajar IPA. Hal ini didukung oleh perolehan rerata skor hasil belajar IPA dengan metode inkuiri 71.00 yang lebih tinggi dari hasil belajar IPA dengan metode konvensional 62.00 . Fenomena ini menunjukkan hasil belajar IPA akan meningkat bila siswa diajar dengan metode inkuiri. Penggunaan metode inkuiri dapat meningkatkan hasil belajar IPA karena dengan penggunaan metode ini lebih mengaktifkan siswa selama pembelajaran berlangsung. Selain itu dengan metode pembelajaran inkuiri dapat memfasilitasi siswa dengan pengalaman sikap kepemimpinan dan membuat keputusan dalam kelompok, serta memberikan kesempatan pada siswa untuk berinteraksi dan belajar berasosiasi, berargumentasi dengan siswa lain yang berbeda latar belakangnya. Peranan guru dalam pembelajaran inkuiri 
adalah sebagai motivator, fasilitator dan konselor. Kegiatan dalam proses pembelajaran lebih berpusat pada siswa sehingga siswa dalam berkesempatan mengembangkan kreativitas dan potensi kognitif maupun sosialnya.

2. Tidak terdapat pengaruh motivasi belajar terhadap hasil belajar IPA yang sangat signifikan. Hal ini ditandai dengan nilai sig. untuk motivasi belajar $0.350>0.05$ dengan demikian dapat disimpulkan tidak terdapat pengaruh motivasi belajar yang signifikan terhadap hasil belajar IPA. Dengan kata lain, tidak terdapat perbedaan hasil belajar siswa yang memiliki motivasi belajar tinggi dengan siswayang memiliki motivasi belajar rendah.

Fenomena ini menunjukkan siswa yang memiliki motivasi belajar tinggi menimbulkan dorongan yang kuatdari dalam diri untuk berkompetensi sehingga membuat siswa lebih percaya diri dalam menjawab soal, belajar lebih senang karena tidak ada unsur paksaan, kesadaran tinggi lebih besar dan merasa bertanggung jawab. Siswa yang memiliki motivasi belajar tinggi sudah barang tentu hasil belajarnyapun akan meningkat sementara siswa yang memiliki motivasi belajar rendah dalam kegiatan belajar sudah barang tentu hasil belajarnya akan menurun.

3. Tidak terdapat pengaruh interaksi antara metode belajar dan motivasi belajar siswa terhadap hasil belajar IPA. Hal ini ditandai dengan nilai sig. $0.815>0.05$ dan $\mathrm{F}_{0} 0.055$. Dengan demikian $\mathrm{H}_{0}$ diterima dan $\mathrm{H}_{1}$ ditolak sehingga dapat disimpulkan tidak terdapat pengaruh interaksi antara metode belajar dan motivasi belajar siswa terhadap hasil belajar IPA.

Berdasarkan hasil ANOVA, terlihat bahwa interaksi yang terjadi antara metode pembelajaran dan motivasi 
belajar siswa pada pelajar IPA nerupakan interaksi yang tidak meyakinkan. Karena tidak adanya interaksi, maka tidak dilakukan analisis lanjutan untuk melihat simple effect diantara sub-sub faktor yang membangun interkasi tersebut. Berdasarkan uraian di atas maka dapat disimpulkan bahwa tidak terdapat pengaruh interaksi metode pembelajaran dan motivasi belajar siswa terhadap hasil belajar IPA.

Metode belajar merupakan suatu patokan dalam menyusun kegiatan belajar siswa di sekolah. Sudah seharusnya seorang guru mempersiapkan rencana belajar, metode belajar yang digunakan dan instrumen yang sesuai dengan perencanaan. Selain itu motivasi belajar merupakan salah satu faktor tertentu penentu keberhasilan belajar siswa di sekolah. Tentu saja persiapan metode pembelajaran yang matang akan menumbuhkan motivasi belajar anak yang akan berdampak positif pada hasil belajar anak. Namun pada kenyataannya dalam penelitian ini tidak ditemukan adanya pengaruh interaksi antara metode belajar dan motivasi belajar siswa terhadap hasil belajar IPA. Hal ini mungkin terjadi bahwa dalam pemilihan sampel dan pelaksanaan eksperimen terjadi kesalahan atau terdapat variabel pengganggu yang tidak dikontrol oleh peneliti.

\section{PENUTUP}

Berdasarkan dari hasil pengujian hipotesis penelitian dan analisis pengolahan data, maka dapat disimpulkan sebagai berikut:

1. Terdapat perbedaan pengaruh yang signifikan antara metode belajar inkuiri dengan metode belajar konvensional terhadap hasil belajar IPA siswa. Hal ini dapat dibuktikan dari sig 0.002 $<0.05$ dan $\mathrm{F}_{0}=10.10$.

2. Tidak terdapat pengaruh yang signifikan antara motivasi belajar terhadap hasil belajar IPA siswa. Hal ini dapat 
dibuktikan dari sig. $0.350>0.05$ dan $\mathrm{F}_{0}=0.887$

3. Tidak terdapat pengaruh interaksi antara metode belajar dan motivasi belajar siswa terhadap hasil belajar IPA. Hal ini ditandai dengan nilai sig. untuk metode belajar dan motivasi belajar $0.815>0.05$ dan $F_{\text {hitung }} 0.055<\mathrm{F}_{\text {tabel }} 4.02$

\section{DAFTAR RUJUKAN}

Amri, Sofan dkk. (2010. Proses Pembelajaran Kreatif dan Inovatif dalam Kelas. Jakarta: PT. Prestasi Pustakaraya.

Arikunto, Suharsimi. (2008). Dasardasar Evaluasi Pendidikan. Jakarta: Bumi Aksara.

(2007). Prosedur Penelitian Suatu Pendekatan Praktek. Jakarta: Rineka Cipta.

Desviranty Imran. (2011). Pengaruh Metode Pembelajaran Dan Minat Belajar Terhadap Hasil Belajar IPA. Unindra PGRI (Tidak diterbitkan)

Dimyati dan Mudjiono. (2009). Belajar dan Pembelajaran. Jakarta: PT Rineka Cipta.

Emzir. (2011). Metodologi Penelitian Pendidikan. Jakarta: Rajawali Press.
Hamalik, Oemar. (2009). Proses Belajar Mengajar. Jakarta: Bumi Aksara.

Purwanto. (2011). Evaluasi Hasil Belajar. Yogyakarta: Pustaka Pelajar.

Reid, Gavin. (2007). Memotivasi Siswa di Kelas. Jakarta: Indeks.

Riyanto, Yatim. (2009). Paradigma Baru Pembelajaran. Jakarta: Prenada Media Group.

Sabri, Ahmad. (2010). Strategi Belajar Mengajar. Jakarta: PT. Ciputat Press.

Sagala, Syaiful. (2010). Konsep dan Makna Pembelajaran. Bandung: Alfabeta.

Samatowa, Usman. (2010). Pembelajaran IPA di Sekolah Dasar. Jakarta: Indeks.

Sanjaya, Wina. (2009). Strategi Pembelajaran Berorientasi Standar Proses Pendidikan. Jakarta: Prenada Media Group.

Sapriati, Amalia dkk. (2011). Pembelajaran IPA di SD. Jakarta: Universitas Terbuka (Tidak diterbitkan).

Sardiman. (2010). Interaksi \& Motivasi Belajar Mengajar. Jakarta: PT. Rajagrafindo Persada.

Slameto. (2010). Belajar dan Faktorfaktor yang Mempengaruhinya. Jakarta: Rineka Cipta. 
Sugiyono. (2010). Statistika untuk Penelitian. Bandung: CV Alfabeta.

Sudjana, Nana. (2009). Penilaian Hasil Proses Belajar Mengajar. Bandung: PT. Remaja Rosda Karya.

Suryosubroto. (2009). Proses Belajar Mengajar. Jakarta: Rineka Cipta.

S. Margono. (2004). Metodologi Penelitian Pendidikan. Jakarta: Rineka Cipta.

Sukmadinata, Syaodih Nana. (2009). Metode Penelitian Pendidikan. Bandung: Rosda.

Sutikno, Sobri. (2009). Belajar dan Pembelajaran. Bandung: Prospect.

Trianto. (2011). Mendesain Model Pembelajaran Inovatif Progresif. Jakarta: Putra Grafika.

Uno, Hamzah B. (2008). Teori Motivasi dan Pengukurannya. Jakarta: PT. Bumi Aksara. 
